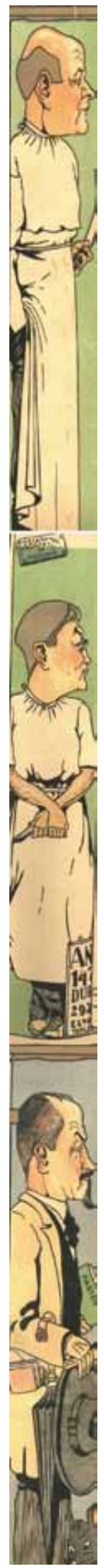

\title{
Profesor Dr. Sofia Ionescu-Ogrezeanu (1920-2008)
}

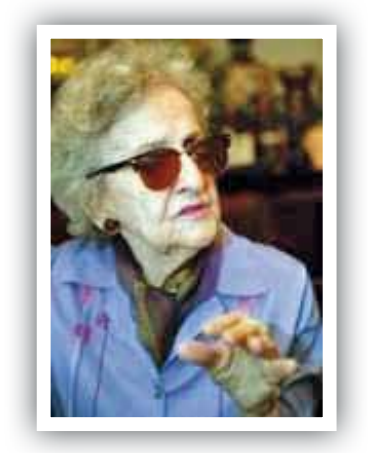

Oficial a fost recunoscută ca prima femeie neurochirurg din lume la Congresul Mondial al Femeilor Neurochirurg din 2005. A practicat neurochirurgia 40 de ani, specializându-se în operații pe creier și coloana vertebrală, efectuând mii de operații. Viața sa a început la Fälticeni, tatăl era funcționar superior la Banca Națională, iar mama, casnică. A urmat școala primară și primele șase clase de liceu în orasul natal, iar ultimele două clase de liceu la Școala Centrală de Fete din București. A făcut studii strălucite la Facultatea de Medicină din București, urmând cursurile celor mai buni dintre medicii pe care $i$-a avut vreodată medicina românească: Francisc Rainer la anatomie, Alfred Rusescu la pediatrie, profesorul Zotta la parazitologie si Dimitrie Bagdasar la histologia sistemului nervos. In timpul facultătii a efectuat primul stagiu de practică la oftalmologie, iar al doilea în comuna Baia, de lângă Fălticeni, în timpul unei epidemii de tifos exantematic. Un an mai târziu s-a oferit să îngrijească prizonierii ruși internati la Spitalul "Stamate” din orașul natal, alăturându-se serviciului de chirurgie. Acolo avea să realizeze primele sale intervenții chirurgicale, majoritatea amputări de picior. Marea întâlnire cu neurochirurgia, un domeniu nou în acea epocă, avea să se petreacă la 15 octombrie 1943, când a devenit intern la Spitalul nr. 9 din Bucuresti, intrând în prima echipă neurochirurgicală, considerată "echipa de aur”, alături de Prof. Dr. Dimitrie Bagdasar, intemeietorul neurochirurgiei românești. De la el a deprins marea pasiune pentru regina artelor chirurgicale, neurochirurgia, cum a fost numită de celebrul medic englez Grafton Lowe. Devine o personalitate cunoscută in intreaga lume pentru contribuțiile sale remarcabile în domeniul neurochirurgiei și pentru lucrările sale științifice apărute în Acta Chirurgica Belgica, Journal de chirurgie, Neurologia, Psibiatria, Neurologia, Neurochirurgia, Revue Roumaine d'Endocrinologie. Profesor universitar, membru al Societății Române de Istoria Medicinii (1996), Membru Emerit al Academiei de Stiințe Medicale (1997), a fost declarată medic erou de către OMS. A primit „Semnul de Distincție” al Crucii Roșii (1943), iar în 1996, Diploma de Onoare ANFDUR, Premiul Elisa Leonida Zamfirescu" si Diploma de Onoare a Confederației Nationale a Femeilor din România. In 1990, a fost nevoită să se pensioneze, din cauza slăbirii vederii. Intr-un interviu, spre sfârșitul vieții afirma: $\hat{I m i}$ pare rău că nu mi-am găsit timp să-mi scriu memoriile. As fi putut să spun tinerilor neurochirurgi cum am făcut meseria asta. As fi putut să descriu tehnici inedite, folosite ad-hoc în situații imprevizibile și nenumărate întâmplări cu rezultate fericite. Pentru că munca mea din acești 47 de ani ar fi incăput foarte bine în două vieți. As fi avut ce să le spun! Copiii mei n-au avut mamă..."

\section{Referințe:}

http://about-brain.blogspot.com/2008/09/

http://www.monitorulsv.ro/Local/2008-03-24/

http://ro.wikipedia.org/wiki/

prof. dr. Rumelia Koren

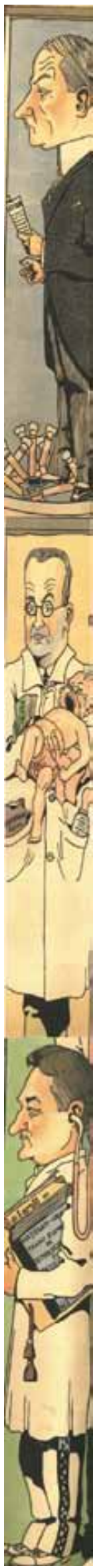

